\title{
A mini review on a Caralluma tuberculata $N$. E. Br. uncommon and wild succulents but having exciting pharmacological attributes
}

\author{
Sobia Noreen* \\ Department of Chemistry, University of Sargodha, Sargodha, 40100-Pakistan \\ *Corresponding author's email: sobianoreen@uos.edu.pk \\ Citation \\ Sobia Noreen. A mini review on a Caralluma tuberculata N. E. Br. uncommon and wild succulents but having \\ exciting pharmacological attributes. Pure and Applied Biology. Vol. 6, Issue 2, pp748-761. \\ http://dx.doi.org/10.19045/bspab.2017.60080
}

Received: $22 / 04 / 2017$

Revised: 04/06/2017

Accepted: 13/06/2017

Online First: 15/06/2017

\section{Abstract}

Caralluma tuberculata belongs to milky weed family Apocynaceae which upholds 424 genera. This natural medicinal plant is widely distributed in South Asia, Africa, Middle East, and Spain etc. Overall phytochemistry of Caralluma tuberculata is endowed with flurry of pharmacologically active constituents like pregnane glycosides and aglycones, flavanoid, saponins and titerpenes etc. Caralluma tuberculata and its various other species of this genus have been explored for their anti-inflammatory action, strong hypoglycemic and weight reduction effect, quite effective for rheumatoid arthritis, paralysis stomach disorders, abdominal pain, migraine, fever wound healing and cardiac problems. Present review focuses on the comprehensive profile of Caralluma tuberculata with respect to its highly valuable phytoconstituent along with their available pharmacological characteristics and therapeutic prospective.

Keywords: Caralluma tuberculata; Desert Succulents; Antidiabetic; Cancer; Obesity;

\section{Pharmacological}

\section{Introduction}

Natural product term widely cover the natural bio source products i.e. plant, animal and microbes. It may be in the form of a mix or single pure compound (secondary metabolites) like alkaloids, limonoids, steroid, flavonoid, lignana, terpenoids, organosulfur, tannin, furyl, polylines, chlorophyllins, thiophenes, saponins, sulphides, coumarins, etc. [1]. The worth of medicinal plants lies in these metabolites that are non-nutritive for plants but produce certain physiological action in plants and human against different types of infectious disease and metabolic disorders [2]. These natural constituents can be classified into two groups on the basis of their role in metabolism. Construction and maintenance of plant body is carried out by primary constituents. There was a thought in history that secondary constituents have no vital role in building or continuance of body of a plant but at present their ecophysiological role has been established. They act as 
defensive tool and attract pollinators or symbionts towards plant. These are also involved in growth regulation, modulation of genetic expression and transduction of signals. Some secondary components mimic body chemicals like signaling molecules, ligands, hormones, neurotransmitters and may act as activators or inhibitors of target cells. Above cited properties can be used to benefit human body such as cytotoxic secondary components for microbes can act as effective antimicrobial agent in human body. Constituents used as defense by plants against herbivores may affect Central Nervous System of human being and act as muscle relaxant, sedative, antidepressant or anesthetic $[3,4]$.

Phytotherapy history is as old as the history of humankind itself [5]. People believe that locally originated diseases can be cured by local remedy [6]. Natural plant products are considered to be in good health than artificial medicine [7].There are many side effects that are caused by the use of allopathic medicines [8]. The medicinal efficacy of antibiotics existing today is decreasing by the appearance of multidrugresistant microbes [9]. Unlike synthetic medicines, phytomedicines may produce their positive effects by additive and synergetic action of many chemical components that act on their target sites to produce a physiological change [10].

Mostly the formulation schemes were kept secret by traditional healers, herbalist and shaman who pose as major obstacle to check the authenticity of these formulations on scientific basis [11]. Despite of ever increasing human knowledge regarding conventional usage of natural products; appropriate modern scientific approaches have only been applied to a very little part of the world's flora. It is matter of grave concern to exploit the potential of those plant species that are in waiting line before they become endangered [12].

\section{Preface to genus Caralluma and Caralluma tuberculata N. E. Br.}

Caralluma etymology considered to come from an Arabic word "qarh al-luhum" the meaning of which is wound inside abscess/flesh probably relate with the milky latex of stem [13]. Caralluma is considered in family Apocynaceae that comprises three subfamilies Rauvolfioideae, Apocynoideae and Asclepiadaceae holding 424 genera [14]. Ornamental plants like Allamanda, Frangipani, Oleander, Vinca of tropical area, large trees with special buttress roots of rainforests and deciduous or evergreen trees, climbers or shrubs of world warm and temperate regions are included in these genera. Milky latex of most of the plants is considered important for medicinal purpose and rubber production. Later, in 1890 Robert Brown separated Asclepiadaceae (milkweed family) from Apocynaceae. Recent advances in genomic, molecular and morphological analysis merge the Asclepiadaceae and Periploceae into Apocynaceae family [15, 16]. Common members of this family are $C$. tuberculata, $C$. edulis, $C$. negevensis, $C$. sinaica, C. russeliana, C. stalagmifera, $C$. dalzielii N. E. Br, C. arabica etc. Among these Caralluma tuberculata occupy a significant position.

Caralluma tuberculata is a member of milkweed family Asclepiadaceae which include about 2500 species from 200 genera and widely distributed in Pakistan, Afghanistan, Africa, Middle East, Spain, Saudia and India [17]. In Pakistan, Asclepiadaceae is represented by approximately 23 genera along with 40 species abundantly present in some tropical regions of Punjab, Khyber Pakhtunkhwa and Blouchistan provinces. Caralluma species have been used for centuries in semiarid areas of Pakistan as emergency food.

Caralluma turbeculata vernacular name is chunga or chung in Punjab. Plants belonging 
to the genus Caralluma are normally leafless [18]. This perennial herb has $15-45 \mathrm{~cm}$ height with a succulent, fleshy leafless, erect and 4 angled stem having grooves on it. Quadrangular stem bear small flowers in several varieties of dark colour [19]. Sessile single or many flowers in lateral cymes having ovate-lanceolate five sepals and deeply divided, glabrous, lobe lanceolate dark purple colour corolla of about $9 \mathrm{~mm}$ in diameter. Anthers are without appendages and each having pollen mass one. Glabrous Follicles with size about $9-11 \mathrm{~cm}$ are progressively tapering to the tip. Flowering season is June. It mostly grows widely on rocks after rain but it is also cultivated in some areas. Its stem and roots are not only eaten raw as famine food but also cooked due to its pharmacological potential. The complete taxonomical classification of Caralluma tuberculata is deciphered in Figure 1.

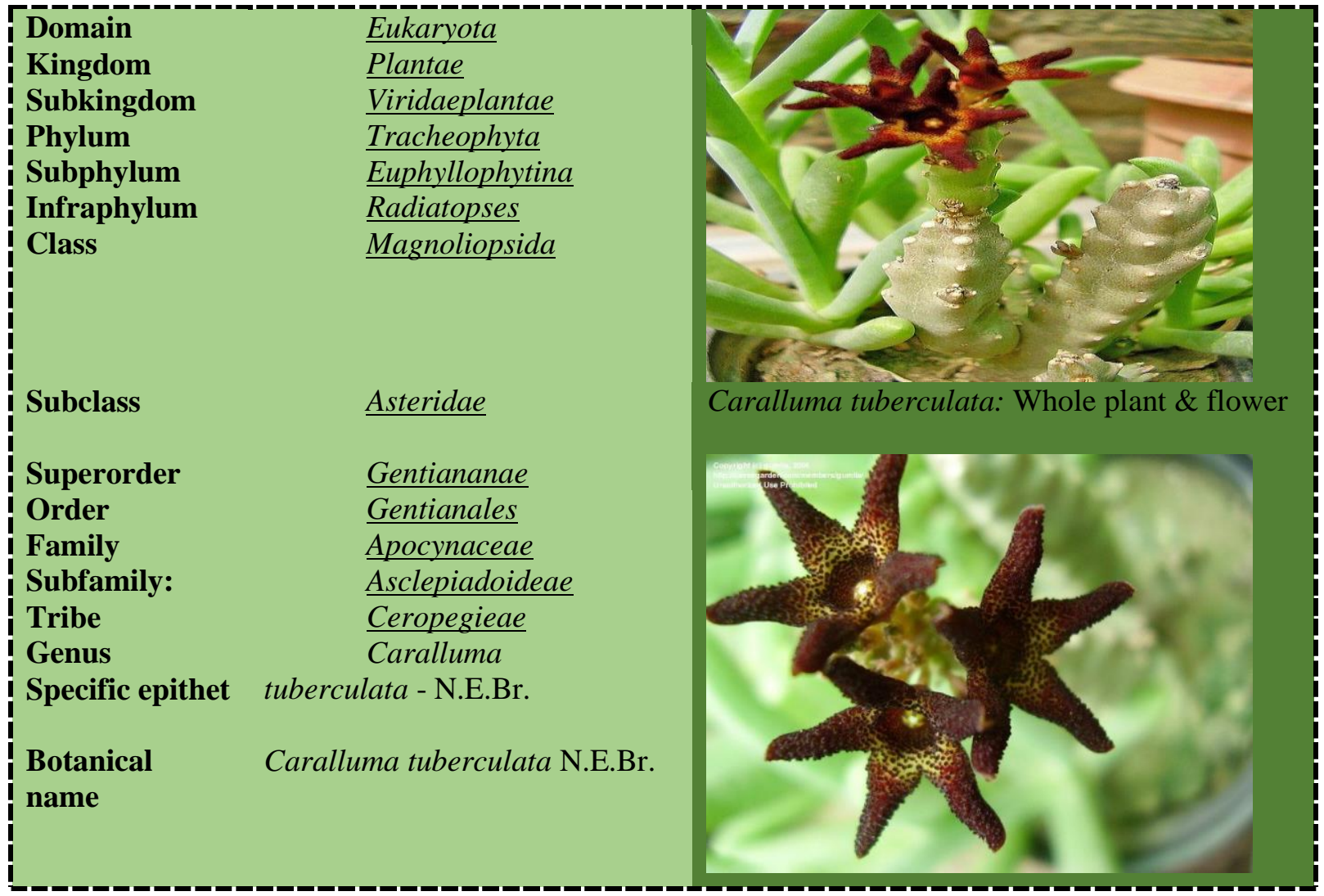

Figure 1. Taxonomy of Caralluma tuberculata N.E.Br. and whole plant along with flower

\section{Phytochemistry}

The succulent Cactus Caralluma contains glycosides, flavonoid, saponins and triterpenes as major phytoconstituents. Genus Caralluma was $1^{\text {st }}$ time explored for its constituents in 1967 and two compounds (dihydrosarcostin, $(20 S)-$ hexahydroxypregnane and tomentogenin ((20S)-pentahydroxypregnane) were extracted from C. dalzielii [20].
Caralluma species, in general, are famous for the presence of their key components i.e. glycosides specifically pregnane glycosides and aglycone steroid [19]. Pregnanes are the C-21 steroides having perhydro-1,2cyclopentanophenanthrene ring as backbone that have $\beta$-oriented methyl group at two position (C-10 and $\mathrm{C}-13)$ and two outside chains of carbon atoms at C-17. In derrvitized form of pregnane the $\beta$ 
confirmation is present along with a hydroxyl group at C-14 [21].

The literature survey indicates that the pregnane glycocydes were isolated from various parts of the plant. With polar solvents like ethylacetate, n-butanol, methanol, ethanol and water, the compounds like $\mathrm{C}_{21}$ class of steroidal glycosides with high molecular weight compounds were obtained but on other hand compounds having low molecular weight like cumarin, sterol, steroid, terpenoid were obtained when the same parts were extracted with non-polar solvents like n-hexane, benzene etc.

Some studies report the presence \& isolation of new pregnane glycosides carumbellosides I and II and a steroidal glycosides i.e. carumbellosides III-V were isolated from the extract of Caralluma umbellate whole plant [22, 23]. New steroidal glycosides, stalagmosides I-V and indicosides I and II together with the known compounds Carumbelloside III, lasianthoside A and lasianthoside B were isolated from whole plant of Caralluma stalagmifera. The genus is also characterized by the presence of flavones glycosides [24].

Two novel steroid glycosides were isolated from Caralluma tuberculata that exhibited fairly in vitro cytotoxic activity on breast cancer cells even in micromolar concentration. Pregnanes are $\mathrm{C}_{21}$ steroids and often found in nature conjugated as glycosides. A flurry of pregnane glycosides and esterified polyhydroxypregnane were extracted from Caralluma and other family member of Asclepiadaceae. Some of these glycosides appear as novel potential template for drug development against cancer and tumor [25].

Chemical investigation of Caralluma tuberculata indicates that it was endowed with the flavone glycosides and several pregnane glycosides [26, 27]. Five pregnane glycosides were isolated from Caralluma tuberculata, in addition to a known one (russelioside E, 6). All these six compounds were checked for their action against malarial and trypanosome. Moreover their cytotoxic effect was also tested on the growth human MRC5 embryonic cell line [28]. Caratuberoside C (I), and D (II), two new pregnane glycosides were isolated from Caralluma tuberculata [29]. A medicinal herb, Caralluma tuberculata, furnished a pregnane type compound, caratuberside $\mathrm{A}_{2}$. The sugar linkage was at $\mathrm{C}-14$ which is a rare site of substitution [30]. Glycone moieties include different sugars like glucose, digitalose, thevotose, quinvose etc. Key phytochemical ingredients of Caralluma umbellate include pregnane glycosides, flavone glycosides, bitter principles, saponins and various flavonoids $[31,32]$. Some acylated pregnane glycosides like russeliosides $\mathrm{E}-\mathrm{H}$ were obtained from chloroform extract of Caralluma russeliana [28].

The aglycone pregnane (Pregnane-14 $\beta$ formyl-5, 7-dien-20-one), with unusual formyl group at $\mathrm{C}-14$, were extracted from of the non polar (petroleum ether) extract Caralluma umbellate stem [33]. Similarly two more aglycone steroids Crur I and Crur II were extracted from the nonpolar extract of the roots of same plant [22]. Furthermore, in another study, one more compound i.e. $20 S$-epimer of boucerin was extracted $1^{\text {st }}$ time from the tolune extract of above said specie of Caralluma [34].

Recently megastigmane glycosides also have been isolated from Caralluma negevensis with few flavones. Saponins and flavonoids predominantly found in Caralluma are of great interest due to the wide range of immunostimulating activities. In Caralluma attenuata, the fresh whole plant contains luteolin-4-Oneohesperidoside, a flavonoid (flavones glycoside) identified as the major chemical 
constituents of the plant. Caralluma adscendens is declared to contain saponin glycosides, bitters, pregnane glycosides (caratubersides $\mathrm{A}$ and $\mathrm{B}$ and various boucerosides) [35].

Several members of the genus Caralluma are rich in triterpenes, pregnane glycosides or their esters which may have found medicinal uses. Triterpenes squalene, lupeol, lupenone, lupeol acetate, $\beta$-sitosterol acetate and guimarenol were extracted from Caralluma buchardii [36].

Pharmacological worth of Caralluma tuberculata and other species of Caralluma

Traditionally it was believed that Caralluma tuberculata has anti-inflammatory and strong hypoglycemic effect [37, 38]. It is also reputed for the treatment of rheumatoid arthritis, paralysis and fever [39].

Table 1. Global distribution and pharmacological activities of different species of Caralluma genus [40]

\begin{tabular}{|c|c|c|c|c|}
\hline $\begin{array}{l}\text { Species of } \\
\text { Caralluma Genus }\end{array}$ & Distribution & Pharmacological Activities & $\begin{array}{l}\text { Part Used in } \\
\text { traditional } \\
\text { medicine System }\end{array}$ & Citations \\
\hline C. adscendens & India & Rheumatic Pain, Paralysis & Plant Stem & {$[41,42]$} \\
\hline C. attenuate & Spain, India & Anti-tumor, Pain, Hyperglycemia & Whole Plant & {$[43,28]$} \\
\hline C. edulis & Pakistan, Iran & $\begin{array}{l}\text { Rheumatic Pain, Parasitic diseases, } \\
\text { Gastric problems, Leprosy, } \\
\text { Hyperglycemia, Hypertension, } \\
\text { Hypercholesterolemia }\end{array}$ & Whole Plant & {$[44,45,46]$} \\
\hline C. umbellate & India & Gastric Ulcers \& Pain & Roots & {$[47,22]$} \\
\hline C. laciantha & India & Wound Healing, Veterinary Use & Plant Stem & {$[41]$} \\
\hline C. stalagmifera & India & Wound Healing, Malnutrition & Plant Stem & [41] \\
\hline C. sinaica & Saudi Arabia & $\begin{array}{l}\text { Hyperglycemia, } \\
\text { Hypercholesterolemia }\end{array}$ & Leaves & {$[48,49]$} \\
\hline C. diffusa & India & Organogenesis, Hyperglycemia, & Whole Plant & {$[50,51]$} \\
\hline C. penicillata & Saudi Arabia & Trypanosomacidal, Antivenom & Whole Plant & [40] \\
\hline C. russeliana & Saudi Arabia & Medicinal & Whole Plant & {$[40]$} \\
\hline C. bhupenderiana & India & Ethnoveternary uses & Whole Plant & {$[52]$} \\
\hline C. fimbriata & India, Iran & $\begin{array}{l}\text { Obesity, Hyperglycemia, } \\
\text { Hypercholesterolemia }\end{array}$ & Plant Stem & {$[41,53,54]$} \\
\hline C. europaea & Italy & Pharmaceutical & Fruits \& Stem & {$[55]$} \\
\hline C. negevensis & Africa, Spain & Anti Cancer, Lung Diseases & & {$[56]$} \\
\hline C. diazielli & Nigeria & $\begin{array}{l}\text { Obesity, Hyperglycemia, } \\
\text { Hypercholesterolemia }\end{array}$ & & {$[57]$} \\
\hline C. nilagiriana & India & Infectious Diseases & & [58] \\
\hline C. wissmannii & Egypt & Medicinal & $\begin{array}{l}\text { Above Ground } \\
\text { Parts }\end{array}$ & [18] \\
\hline C. arabica & UAE & $\begin{array}{l}\text { Vegetable, Liver Tonic, Obesity, } \\
\text { Hyperglycemia, Hypercholesterolemia, } \\
\text { Wound Healing }\end{array}$ & Whole Plant & [59] \\
\hline C. pauciflora & India & Vegetable & Plant Stem & {$[52]$} \\
\hline $\begin{array}{l}\text { C. tuberculata N. } \\
\text { E. Br. }\end{array}$ & $\begin{array}{l}\text { Pakistan, } \\
\text { India, Iran, } \\
\text { Nigeria, Saudi } \\
\text { Arabia }\end{array}$ & $\begin{array}{l}\text { Vegetable, Hepatitis B \& C, Blood } \\
\text { Purification, Gastric Problems, Liver } \\
\text { Tonic, Obesity, } \\
\text { Hyperglycemia,Hypercholesterolemia }\end{array}$ & Whole Plant & $\begin{array}{l}{[38,44,46,} \\
60-66,]\end{array}$ \\
\hline
\end{tabular}

Caralluma family members are rich with Pregnane that naturally conjugated with glycoside and its structure encomprises basic C21steroids backbone along with 
sugar moiety. These molecules appear as potential lead for drug development against cancer and diabetes [20, 21]. Pregnane glycosides series has been extracted from its organic extracts that explicit cytoxic effect against cell line of Human diploid embryonic cell like MRC5 [28].

Antiproliferative potential of Caralluma tuberculata N. E. Br. was observed on the growth of estrogen-dependent (MCF-7), and estrogen-independent

(MDA-MB-468)

breast cancer cells, U937 and Caco-2 colonic cells [25]. Androstan and pregnane glycosides stimulate caspase mediated apoptosis. Caspase enzyme, dependent on Calcium, is activated via two possible pathways, intrinsic (e.g. mitochondria damage) and extrinsic (e.g. cell surface death receptors ligation). This activated caspase along with caspase 3 trigger the cleavage of poly-(ADP ribose) polymerase (PARP) and DNA fragmentation. After PARP cleavage, cell irrevocably prone to apoptosis. Due to structural homology of Pregnane glycosides with estrogen agonist inhibits Calcium exchangers, as a result calcium concentration increased that stimulate caspases and apoptosis [20]. Other possibility is activation of the xenobiotic and steroid receptors that also induce the apoptosis process in cancerous cells of breast [67]. Mechanism of induction of apoptosis by the pregnane compound is shown in Figure 2. This process is not fully cleared hence further research is mandatory to decipher the activation of xenobiotic receptors.

Treatment with Caralluma tuberculata N. E. Br. extract induced complex biochemical and cytological changes in mice [68]. The ethanolic extract of Caralluma tuberculata afforded potential protection against gastric mucosa injuries caused by $80 \%$ ethanol, 0.2 $\mathrm{M} \mathrm{NaOH}$, hypertonic saline and indomethacin in a dose-dependent manner [26]. Many flavonoids such as Quercetin, rutin, Kaempferol, flavone glycoside and hypolaetin-8-glucoside have been reported to have gastric ulcer protective effects. Similarly saponins, such as the derivatives of glycyrrhetinic acid and triterpenoid saponins were also reported to have antiulcer effects in rats. It therefore appears responsible to suggest that flavonoids and saponins in Caralluma tuberculata may be totally or partially responsible for its antigastric ulcer activity [69]. Pregnane glycosides, Penicilloside E showed the highest antitrypanosomal activity (IC50 1.01 $\mu \mathrm{g} / \mathrm{mL}$ ) followed by caratuberside C (IC50 $1.85 \mu \mathrm{g} / \mathrm{mL}$ ), which exhibited the highest selectivity index (SI 12.04). It was noticed that acylation is required for the antitrypanosomal activity while glycosylation at C-20 has no significant effect on the activity.

The methanolic extract of Caralluma tuberculata N. E. Br. as well as its petroleum ether, chloroform and n-butanol extract were also examined for antitrypanosomal and antimalarial potential, additional to their cytotoxic potential against diploid embryonic cell line (MRC5) of human. Six compounds (1-6) were extracted from the chloroform fraction and identified by spectral means and were also tested for their antimalarial, antitrypanosomal and antiprotozoal activity against malaria and trypanosomiasis. As for the anti-malarial activity, only petroleum ether soluble fraction demonstrated moderate inhibitory effect (IC50 $7.94 \mathrm{lg} / \mathrm{mL}$ ), this fraction showed high cytotoxicity on MRC5 (IC50

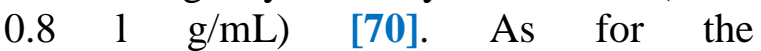
antitrypanosomal activity, the methanolic extract was inactive, while the petroleum ether soluble fraction showed potent activity (IC50 $0.5 \mathrm{lg} / \mathrm{mL}$ ) with a selectivity index of 1.6. On the other hand, the $\mathrm{CHCl}_{3}$ soluble fraction was moderately active (IC50 3.5 $\mathrm{lg} / \mathrm{mL}$ ) with a selectivity index of 17.9. Accordingly, the $\mathrm{CHCl}_{3}$ soluble fraction was 
chosen for isolating the bioactive compounds. Compounds 1-6 were isolated from this fraction and their antimalarial and antitrypanosomal activity were evaluated [28].

Other members of this genus like Caralluma fimbriata and Caralluma siniaca were considered to reduce body weight and blood glucose level respectively [49,54]. Caralluma fimbriata is listed in The Wealth of India (1992) as medicinal plant used as an appetite suppressant and has also been used to treat diabetes, pain, fever, and inflammation [71]. Its pregnane glycosides were thought to inhibit the action citrate layase enzyme and malonyl coenzyme A thus inhibiting the synthesis of fat cells. The blockage of action by this plant extract eventually stimulates the burning process of already stored fat reserves of body and finally reduces circumference of muscles and body lose weight. Caralluma fimbriata extracts have also been found to be appetite suppressant and is well known to Indian tribals and hunters. Indian folklore records its use as a potent appetite suppressant and weight loss promoter [24].

Caralluma edulis is also famous for its antidiabetic potential [72]. Similarly hypoglycemic synergistic effect was noticed when $C$. edulis and $C$. attenuate were used in combination along with extract of phlorizin for reducing blood and urine glucose level in conjunction with weight loss [73]. Figure 3 briefly explains the possible mechanisms of action of Caralluma on the reduction of blood glucose in the animal body. In Nepal and Sri Lanka, stem of wild Caralluma umbellata are used in stomach disorders and abdominal pains [22]. Caralluma adscendens is a thick, succulent perennial herb found wild in Africa, the Canary Islands, India, Arabia, Southern Europe, and Afghanistan. In India, it is found in the dry hills of Andhra Pradesh, Warangal and some other district. It is a traditional food consumed in pickle form and is also eaten during famines [35]. It is locally known as "Makadshenguli/Shengulmakad". The local people use it in raw form for treatment of diabetes and it is also utilized as a vegetable [74]. Caralluma attenuata is eaten raw as a cure for diabetes and the juice of the plant along with black pepper is recommended in the treatment of migraine. It also usually exhibits antinociceptive activity owing to its luteolin-49-O-neohesperidoside components [43].

Caralluma dalzielii N. E. Br. is a succulent herb growing wildly on the Sahelian region of West Africa from Senegal to Nigeria where it was used in folk medicine as antispasmodic and analgesic remedy. Plant latex, in Bandiagara area of Mali, is used for wound healing, while the stems are grounded and eaten raw as tonic and for cardiac problems. A previous phytochemical study on this plant reported the isolation of two tomentogenin esters [75].

In short, worldwide distribution and pharmacological properties of some significant species of Caralluma genus are represented in summarized form in Table 1 and Figure 4. 


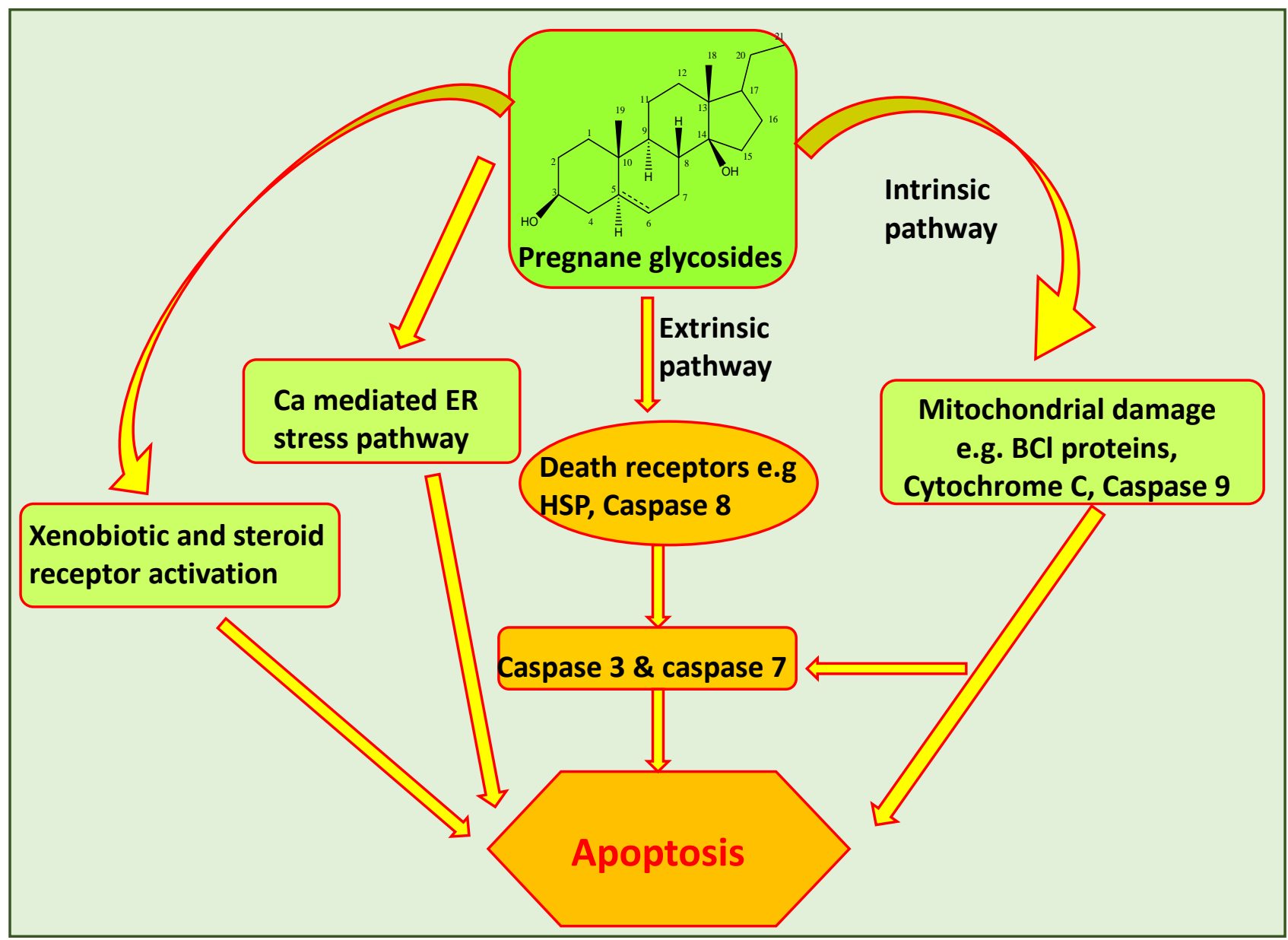

Figure 2. The proposed model of pregnane compound arbitrated apoptosis. Pregnane glycosides of Cralluma tuberculata N. E. Br. are considered in to stimulate the apoptosis process in cancer cell either through caspase dependent (Extrinsic \& intrinsic pathways) or caspase indendent pathways (calcium mediated endoplasmic reticulumn stress pathway and stress \& xenobiotic receptors activation. 


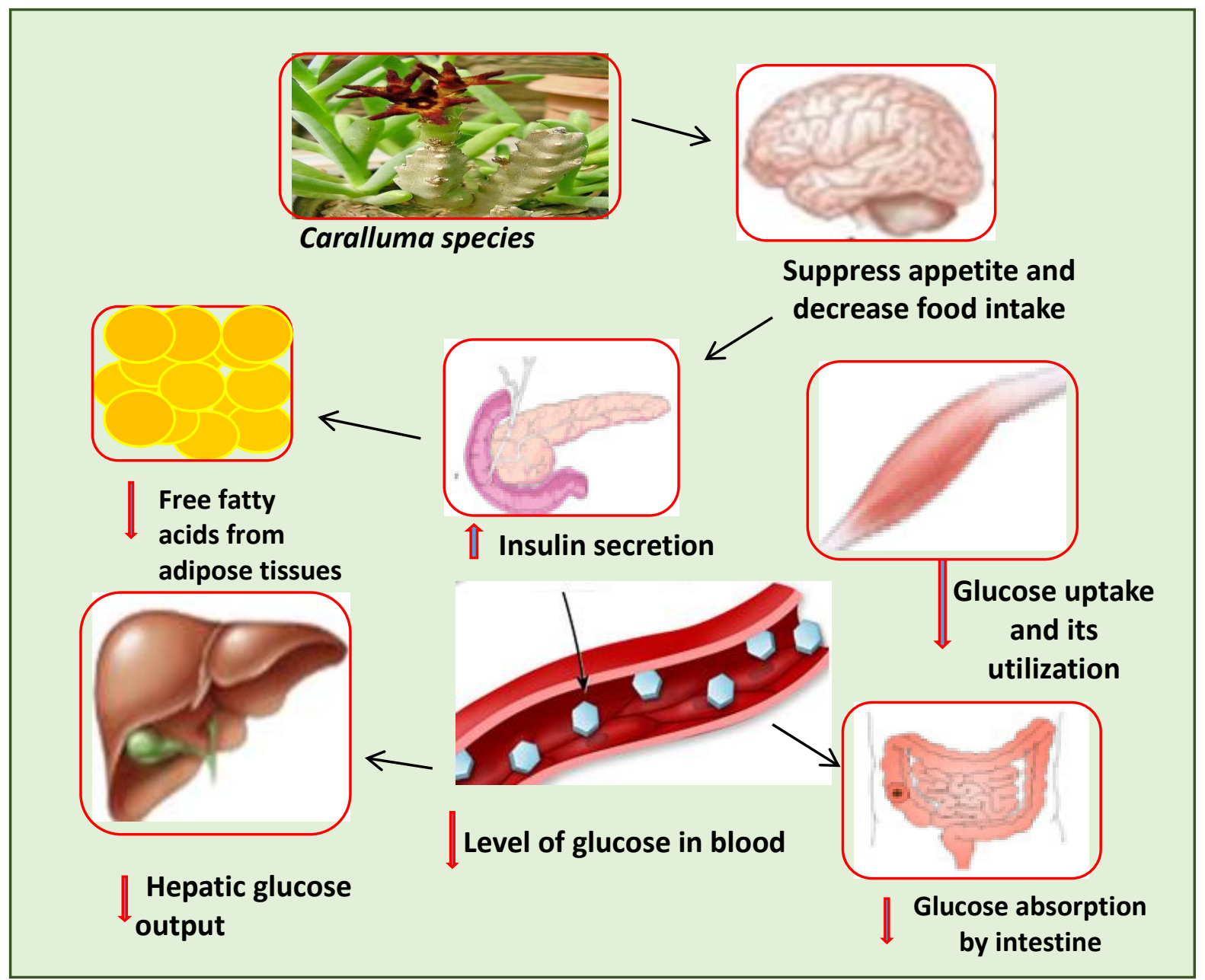

Figure 3. Possible mechanisms of action of Caralluma on the reduction of blood glucose in the animal body 


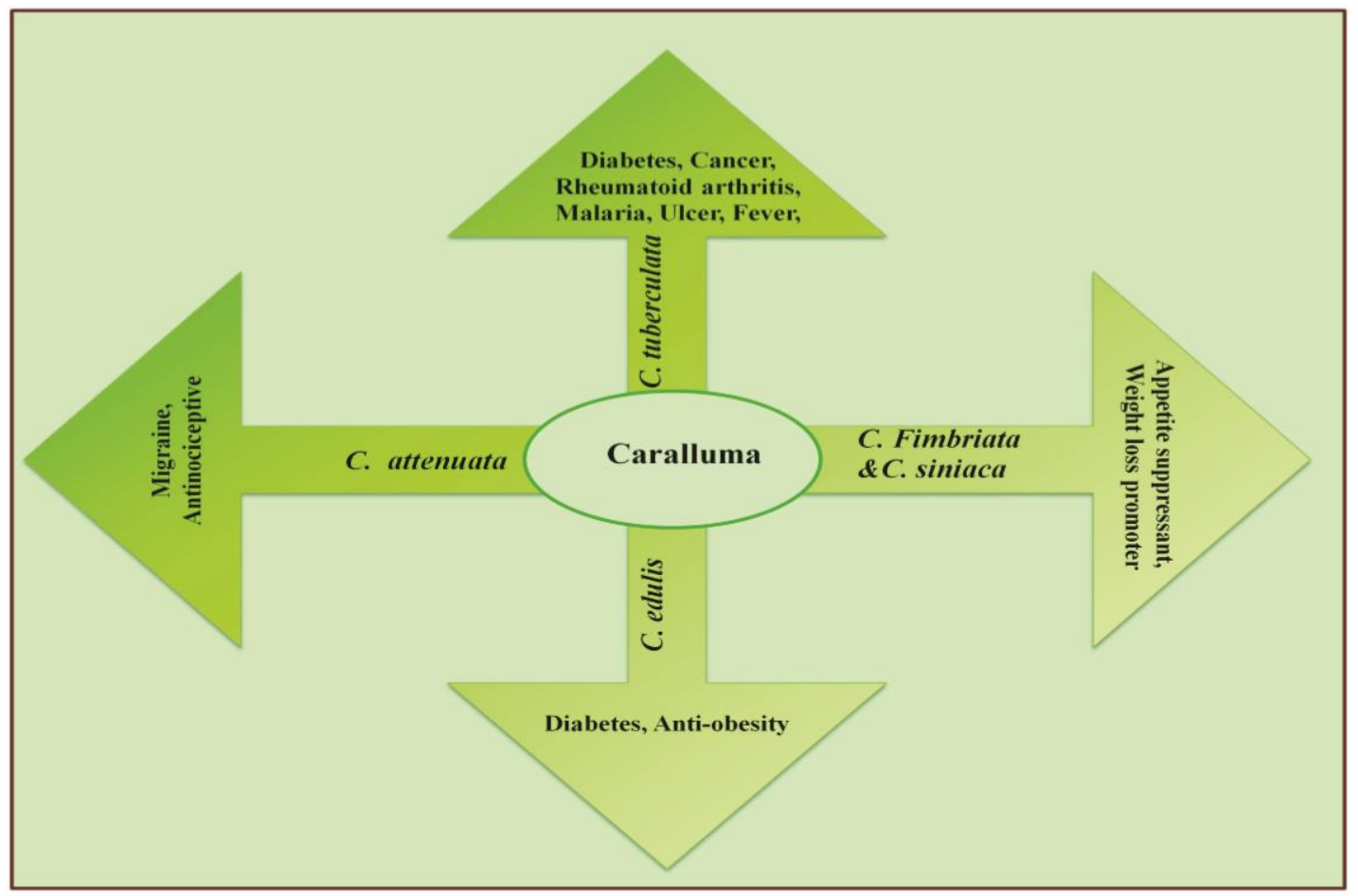

Figure 4. Graphical description of pharmacological features of different species of Genus Caralluma

\section{Conclusion}

Most species of genus Caralluma grow in semiarid and desert area of Asia and Mediterranean region of the world. Key phytochemical ingredients of Caralluma include pregnane glycosides, pregnane aglycones, flavone glycosides, bitter principles, saponins, triterpines and various flavonoids that were explored for various therapeutic purposes against different infectious agents and metabolic disorders. In folklore, Caralluma is famous for hypoglycemic, anti-rheumatic and weight reduction effects. Historically, Caralluma members were also used as vegetable during famine but it is a neglected genus of vegetable worldwide that is rarely cultivated and very little efforts has been made to conserve the species of this genus. Further research on isolated compounds from this genus could improve their biological effectiveness along with future investigation of neglected members from this genus on scientific basis.

\section{Authors' contributions}

Conceived and designed the paper: $\mathrm{S}$ Noreen, Wrote the paper: S Noreen.

\section{References}

1. Naithani R, Huma LC, Holland LE, Shukla D, McCormick DL, Mehta RG \& Moriarty RM (2008) Antiviral activity of phytochemicals: Mini-Rev Med Chem 8: 1106-1133.

2. Edeoga H, Okwu D \& Mbaebie B (2005). Phytochemical constituents of some nigerian medicinal plants. Afr J Biotechnol 4: 685-688.

3. Kaufman PB, Cseke LJ, Warber S, Duke JA \& Brielmann HL (1998). Natural products from plants. CRC Press Inc.

4. Wink M (1998). Functions of plant secondary metabolites and their exploitation in biotechnology. CRC Press 1999.

5. Ahmad I, Aqil F \& Owais M (2006). Mdern phytomedicine: Turning medicinal 
plants into drugs. John Wiley \& Sons. 61 $\mathrm{p}$

6. Winslow LC \& Kroll DJ. Herbs as medicines. Arch Intern Med 158: 21922199.

7. Gesler WM (1992). Therapeutic landscapes Medical issues in light of the new cultural geography. Soc Sci Med 34: 735-746.

8. Deshpande DA (2006). Handbook of medicinal herbs. AGROBIO (India).

9. Bandow JE, Brötz H, Leichert LIO, Labischinski H \& Hecker M (2003). Proteomic approach to understanding antibiotic action. Antimicrob. Agents Chemother. 47: 948-955.

10. Tyler VE, (1999) Phytomedicines. Back to the future. Journal of Natural Products 62: 1589-1592.

11. Kuruvilla A (2002). Herbal formulations as phamacotherapeutic agents. Indian $J$ Exp Biol 40: 7-11.

12. Sasidharan S, Chen Y, Saravanan D, Sundram K \& Latha LY (2011). Extraction, isolation and characterization of bioactive compounds from plants' extracts. Afr J Tradit Complement Altern Med. 8: 1-10

13. Gilbert M A (1990). Review of Caralluma R. Br. and its segregates. Bradleya 8: 1-32.

14. Liede-Schumann S, Rapini A, Goyder DJ, Chase MW \& Plunkett GM (2005). Phylogenetics of the new world subtribes of asclepiadeae (apocynaceaeasclepiadoideae) Metastelmatinae, oxypetalinae, and gonolobinae. Syst Bot 30: 184-195.

15. Endress ME \& Bruyns PV (2000). A revised classification of the apocynaceae sl. Bot Rev 66: 1-56.

16. Meve U \& Heneidak S (2005). A morphological, karyological and chemical study of the apteranthes (caralluma) europaea complex. Bot J Linean Soc 149: 419-432.

17. Swarupanandan K, Mangaly JK, Sonny T, Kishorekumar K \& Basha SC (1996). The subfamilial and tribal classification of the family Asclepiadaceae. Bot J Linean Soc 120: 327-369.

18. Dawidar AM, Mubarak AY, Abdel-Mogib M \& Abdelsattar E. Phytochemical investigation of caralluma wissmannii. Res J Pharm Biol Chem Sci 3: 884-892.

19. Vajha M \& Chillara SRK (2014). Evaluation of cellular antioxidant activity of selected species of caralluma and boucerosia on cell lines. Int J Appl Sci Biotechnol 2: 83-87.

20. Deepak D, Srivastav S \& Khare A (1997). Pregnane glycosides. Fortschritte der chemie organischer naturstoffe/progress in the chemistry of organic natural products: Springer pp. 169-325.

21. Deepak D, Khare A \& Khare MP (1989). Plant pregnanes. Phytochem Lett 28: 3255-3263.

22. Medikondu K, Surendrababu K, Hanumantharao Y, Naga hima bindu G \& Janardhan M (2010). Chemical examination of medicinal plant "Caralluma umbellate" (asclepiadaceae) roots. Int J Appl Biol 1: 545-549.

23. Qiu SX, Cordell GA, Kumar BR, Rao YN, Ramesh M, Kokate C \& Rao AVNA (1999). Bisdesmosidic pregnane glycosides from Caralluma lasiantha. Phytochem Lett 50: 485-491.

24. Sreelatha V \& Pullaiah T (2010). Induction of somatic embryogenesis and plant regeneration from intermodal explants of Caralluma stalagmifera. Bot Res Int 3: 17-20.

25. Waheed A, Barker J, Barton SJ, Khan GM, Najm-us-Saqib Q, Hussain M, Ahmed S, Owen C \& Carew MA (1989). Novel acylated steroidal glycosides from Caralluma tuberculata induce caspasedependent apoptosis in cancer cells. $J$ Ethnopharmacol 137: 1189-1196.

26. Abdel-Sattar E, Harraz FM, Ghareib SA, Elberry AA, Gabr S \& Suliaman MI (2011). Antihyperglycaemic and hypolipidaemic effects of the methanolic extract of Caralluma tuberculata in streptozotocin-induced diabetic rats. Nat Prod Lett 25: 1171-1179. 
27. Oyama M, Iliya I, Tanaka T \& Iinuma M (2007). Five new steroidal glycosides from Caralluma dalzielii. Helvetica chimica acta 90: 63-71.

28. Abdel-Sattar E, Harraz FM, Al-Ansari SMA, El-Mekkawy S, Ichino C, Kiyohara H, Ishiyama A, Otoguro K, Omura S \& Yamada H (2008). Acylated pregnane glycosides from Caralluma tuberculata and their antiparasitic activity. Phytochem Lett 69: 2180-2186.

29. Rizwani GH, Usmanghani K, Ahmad M \& Ahmad VU (1993). Pregnane glycosides from Caralluma tuberculata. Nat Prod Lett 2: 97-104.

30. Rizwani GH, Ahmad M, Usmanghani K \& Ahmad VU (1993). Caratuberside a2: A new pregnane from caralluma tuberculata. Spectrosc Lett 26: 1427-1434.

31. Sayantan Ray, Abhishek Sharma \& Nagaiah K (2012). Phytochemical and pharmacological re-evaluation of caralluma umbellate. Int. J com. Pharm. 3: $1-2$.

32. Al-Massarani SM, Bertrand S, Nievergelt A, El-Shafae AM, Al-Howiriny TA, AlMusayeib NM, Cuendet M \& Wolfender JL (2012). Acylated pregnane glycosides from caralluma sinaica . Res J Pharm 79: 129-140.

33. Suresh Babu K, Rama Subba Rao V, Vyasa Radhakrishnan S, Madhusudana Rao J \& Siva Rambabu S (2008). A new pregnane steroid from the stems of. $J$ Asian Nat Prod Res 10: 1013-1016.

34. Kunert O, Simic N, Ravinder E, Adavi Rao BV, Ravi Kumar B, Michael Alex R, Kuehnelt D \& Appa Rao AVN (2009). Steroidal glycosides from Caralluma umbellata . Phytochem Lett 2: 134-138.

35. Tatiya A, Kulkarni A, Surana S \& Bari N (2010). Antioxidant and hypolipidemic effect of Caralluma adscendens roxb. Ib alloxanized diabetic rats. Tyler VE. Phytomedicines: Back to the future. $J$ Nat Prod 62: 1589-1592.

36. Castro V, Garcia C, Gonzalez A, Hernandez R \& Suarez E (1980). A 3, 4- seco-triterpene from Caralluma buchardii . Phytochem Lett 19: 2210-2212.

37. Ahmed M, Qureshi S, Al-Bekairi A, Shah A, Rao R \& Qazi N (1993). Antiinflammatory activity of caralluma tuberculata alcoholic extract. Fitoterapia 64.

38. Mahmood T, Muhammad S \& Shinwari ZK (2010). Molecular and morphological characterization of caralluma species. Pak J Bot 42: 1163-1171.

39. Mahmood T, Muhammad S \& Shinwari ZK (2010). Molecular and morphological characterization of caralluma species. Pak J Bot 42: 1163-1171.

40. Adnan M, Jan S, Mussarat S, Tariq A, Begum S, Afroz A \& Shinwari ZK (2015) A review on ethnobotany, phytochemistry and pharmacology of plant genus Caralluma R. Br. J Pharm Pharmacol 66: 1351-1368

41. Naik RM, Venugopalan V, Kumaravelayutham P \& Krishnamurthy Y (2012). Nutritive value and mineral composition of edible caralluma and boucerosia species from the arid areas of karnataka. Int J Agric Environ Biotech 5: 117-125.

42. Gowri S \& Chinnaswamy P (2011). Evaluation of in vitro antimutagenic activity of Caralluma adscendens roxb. In bacterial reverse mutation assay. J Nat Prod Plant Resour 1: 27-34.

43. Kumar AS, Kavimani S \& Jayaveera K (2011). A review on medicinal plants with potential antidiabetic activity. Phytomedicine 2: 53-60.

44. Mahmood A \& Tabassum A (2011). Ethnomedicinal survey of plants from district sialkot. Pakistan J Appl Pharm 2: 212-220.

45. Ali H, Sannai J, Sher H, Rashid A. (2011). Ethnobotanical profile of some plant resources in malam jabba valley of swat, pakistan. J Medi Plants Res 5: 4676-4687.

46. Ahmad M, Qureshi R, Arshad M, Khan MA \& Zafar M (2009). Traditional herbal remedies used for the treatment of diabetes 
from district attock (Pakistan). Pak J Bot 41: 2777-2782.

47. Karuppusamy S (2007). Medicinal plants used by paliyan tribes of sirumalai hills of southern india Nat Prod Rad 6: 436-442.

48. Al-Musayeib NM, Mothana RA, AlMassarani S, Matheeussen A, Cos P \& Maes L (2012). Study of the in vitro antiplasmodial, antileishmanial and antitrypanosomal activities of medicinal plants from saudi arabia. Molecules 17: 11379-11390.

49. Habibuddin M, Daghriri HA, Humaira T, Qahtani MSA \& Hefzi AAH (2008). Antidiabetic effect of alcoholic extract of caralluma sinaica 1. On streptozotocininduced diabetic rabbits. $J$ Ethnopharmacol 117: 215-220.

50. Ramadevi T, Ugraiah A \& Pullaiah $\mathrm{T}$ (2012). In vitro shoot multiplication from nodal explants of boucerosia diffusa wight--an endemic medicinal plant. $J$ Biotechnol 11: 344-347.

51. Karthik P, Samydurai P, Subbaiyan B, Thangapandian V \& Binu T (2013). In vitro propagation of a rare succulent medicinal plant Caralluma diffusa (wight) ne br. Plant Biol 3: 8-17.

52. Ugraiah A, Sreelatha VR, Reddy PK, Rajasekhar K, Rani SS, Karuppusamy S \& Pullaiah T (2013). In vitro shoot multiplication and conservation of Caralluma bhupenderiana sarkaria-an endangered medicinal plant from south india. Afr J Biotechnol 10: 9328-9336.

53. Kamalakkannan S, Rajendran R, Venkatesh RV, Clayton P \& Akbarsha MA (2010). Antiobesogenic and antiatherosclerotic properties of Caralluma fimbriata extract. $J$ Nutr Metab 2010:1-6

54. Lawrence R \& Choudhary S (2004). Caralluma fimbriata in the treatment of obesity. 12th Annual World Congress of Anti-Aging Medicine.

55. Zito P, Sajeva M, Bruno M, Maggio A, Rosselli S, Formisano C \& Senatore F (2010). Essential oil composition of stems and fruits of Caralluma europaea ne Br.(apocynaceae). Molecules 15: 627-638.

56. Braca A, Bader A, Morelli I, Scarpato R, Turchi G, Pizza C \& De Tommasi N (2002). New pregnane glycosides from caralluma negevensis . Tetrahedron 58: 5837-5848.

57. Tanko Y, Daniel P, Mohammed K, Jimoh A, Yerima M \& Mohammed A (2013). Effect of ethanolic extract of Caralluma diazielli on serum lipid profiles on fructose induced diabetes in wistar rats. Scholar Res 4: 162-166.

58. Prabakaran R \& Kalimuthu K (2013). Antibacterial activity of the whole plant of caralluma nilagiriana kumari et subba raoan endemic medicinal plant species. Int $J$ Pharm Bio Sci 4: 42-48.

59. Zakaria M, Islam M, Radhakrishnan R, Chen H, Kamil M, Al-Gifri A, Chan K \& Al-Attas A (2001). Anti-nociceptive and anti-inflammatory properties of caralluma arabica. J Ethnopharmacol 76: 155-158.

60. Shah a, Hussain S, Bhatti KH, Khan A, Marwat SK, Zafar M \& Ahmad M. (2012). Sacred jungles: A traditional way of conserving endangered ecosystems and biodiversity in semi-tribal area, kurd sharif \& sho (district karak, khyber pakhtunkhwa), Pakistan. Sci., Tech. and Dev. 31: 312-326.

61. Shah A, Marwat SK, Gohar F, Khan A, Bhatti KH, Amin M, Din NU, Ahmad M \& Zafar M (2013). Ethnobotanical study of medicinal plants of semi-tribal area of makerwal \& gulla khel (lying between khyber pakhtunkhwa and punjab provinces), Pakistan. Am J Plant Sci. 4: 98-116.

62. Rauf A, Jan M, Rehman W \& Muhammad N (2013). Phytochemical, phytotoxic and antioxidant profile of caralluma tuberculata ne brow. $J$ Pharm Pharmacol 2: 21-25.

63. Safa O, Soltanipoor MA, Rastegar S, Kazemi M, Nourbakhsh Dehkordi K \& Ghannadi A (2012). An ethnobotanical survey on hormozgan province, iran. Avicenna J Phytomed 3: 64-81. 
64. Tareen RB, Bibi T, Khan MA, Ahmad M \& Zafar M (2010). Indigenous knowledge of folk medicine by the women of kalat and khuzdar regions of balochistan, pakistan. Pak J Bot 42: 1465-1485.

65. Marwat SK, Rehman F, Khan EA, Khakwani AA, Ullah I, Khan KU \& Khan IU (2014). Useful ethnophytomedicinal recipes of angiosperms used against diabetes in south east asian countries (india, pakistan \& sri lanka). Pak J Pharm Sci 27: 13338-11358.

66. Zabihullah Q, Rashidc A \& Akhtar N (2006). Ethnobotanical survey in kot manzaray baba valley malakand agency, pakistan. Pak J Plant Sci 12: 115-121.

67. Verma S, Tabb MM \& Blumberg B (2009). Activation of the steroid and xenobiotic receptor, sxr, induces apoptosis in breast cancer cells. BMC cancer 9: 3 .

68. Al-Bekairi A, Qureshi S, Ahmed M, Qazi N, Khan Z \& Shah A (1992). Effect of caralluma tuberculata on the cytological and biochemical changes induced by cyclophosphamide in mice. Food Chem Toxicol 30: 719-722.

69. Alharbi MM, Qureshi S, Raza M, Ahmed MM, Afzal M \& Shah AH (1994). Evaluation of caralluma tuberculata pretreatment for the protection of rat gastric mucosa against toxic damage. Appl Pharmacol 128:1-8.

70. Waheed, A. (2001). Pharmacognostic and phytopharmacological studies of Caralluma tuberculata' and 'Fagonia indica' (Doctoral dissertation, Gomal University, Dera Ismail, NWFP Pakistan).

71. Abdel-Sattar E, Ahmed AA, Hegazy MEF, Farag MA \& Al-Yahya MA-A (2007). Acylated pregnane glycosides from Caralluma russeliana. Phytochem Lett 68: 1459-1463.

72. Wadood A, Wadood N \& Shah S (1989). Effects of Acacia arabica and Caralluma edulis on blood glucose levels of normal and alloxan diabetic rabbits. J Pak Med Assoc 39: 208-212.

73. Venkatesh S, Reddy GD, Reddy BM, Ramesh M \& Rao A (2003). Antihyperglycemic activity of caralluma attenuata . Fitoterapia 74: 274-279.

74. Mali K, Dias R, Hawaldar V \& Mahajan $N$ (2009). Hypoglycemic activity of Caralluma adscendens in alloxan induced diabetic rats. Int J Chem Sci 7: 517-522.

75. De Leo M, De Tommasi N, Sanogo R, Marzocco S, Pizza C, Morelli I \& Braca A (2005). New pregnane glycosides from Caralluma dalzielii. Steroids 70: 573-585. 